\title{
CRUSTAL DEVELOPMENT IN RELATION TO GRANITIC MAGMATISM IN REGARD TO D/H PARTITION BETWEEN COEXISTING HORNBLENDE AND BIOTITE IN THE SVECOFENNIAN BELT
}

\author{
Y. KURODA, T. YAMADA, Y. YAMAGUCHI, H. SATO, \\ Y. WAKE and S. MATSUO
}

KURODA, Y.; YAMADA, T.; YAMAGUCHI, Y.; SATO, H.; WAKE, Y. and MATSUO, S. 1993. Crustal development in relation to granitic magmatism in regard to $\mathrm{D} / \mathrm{H}$ partition between coexisting hornblende and biotite in the Svecofennian belt. Bull. Geol. Soc. Finland 65, Part II, 91-118.

Tie-lines in the $\sigma \mathrm{D}-\mathrm{X}_{\mathrm{Fe}}$ diagram of hornblende and biotite in Japanese island arc granites give commonly a similar slope to that derived from the equation of Suzuoki-Epstein's experimental work(1976). This indicates that in the process of granite intrusion in the island arc environment, the water/rock ratio is high enough to allow the presence of molecular water within and around the rock mass crystallizing from the magma. However, the tie-lines of the anorogenic rapakivi granites of Finland (age 1.65-1.54 Ga) are quite different from those of island arc granites, i.e. the $\sigma \mathrm{D}$ of hornblende is much lower than that of biotite and the $\mathrm{X}_{\mathrm{Fe}}$ values of both of the minerals are almost the same and high (0.8-0.9). Thus, the tie-lines are nearly vertical. Moreover, the $\mathrm{OH}$ contents of hornblende and biotite are very low and this suggests the absence of molecular water in the ascending and crystallizing granitic magma. This probably suggests that the $\mathrm{D} / \mathrm{H}$ fractionation factor between the hydrous silicates and hydroxyl $(\mathrm{OH})$ in the magma without molecular water is different from that of the island arc granites with plenty of molecular water.

For the Svecofennian granitic rocks which are older than the rapakivi, e.g. the Turku, Uppsala, Vänge and Revsund masses, the $\sigma \mathrm{D}-\mathrm{X}_{\mathrm{Fe}}$ relationships of hornblende and biotite change systematically following the chronological order of the intrusion. The $\sigma \mathrm{D}-\mathrm{X}_{\mathrm{Fe}}$ relationships of the granitic rocks around Turku are close to those of the island arc granites, those of the Uppsala and Vänge granites show the intermediate patterns between the Turku and Revsund, and those of the Revsund granites are rather similar to rapakivi. It is considered that the geological settings of granitic magmatism in the Svecofennian belt of the Baltic shield developed from a more mobile to a more continental one.

Key words: granites, rapakivi, hornblende, geochemistry, D/H, igneous activity, fractional crystallization, Svecofennides, Proterozoic, Finland, Sweden.

Y. Kuroda, T. Yamada, Y. Yamaguchi, H. Sato and Y. Wake: Department of Geology, Shinshu University, Matsumoto 390, Japan.

S. Matsuo: Department of Chemistry, The University of Electro-Communication, Chofu, Tokyo 182, Japan. 


\section{INTRODUCTION}

The $\sigma \mathrm{D}-\mathrm{X}_{\mathrm{Fe}^{*}}$ relationships of coexisting hornblende and biotite have been determined for Cretaceous Itype granitic rocks in Japan by Kuroda et al.(1986; ilmenite-series) and Kuroda et al.(1989; magnetiteseries). The magnetite- and ilmenite-series of granitic rocks have been defined by Ishihara (1977). Tie-lines of coexisting hornblende and biotite in the $\sigma D-X_{\mathrm{Fe}}$ diagram of rocks of both series show almost the same slope as that derived from the experimental equation of fractionation factor between water and hornblende or biotite $\left(\alpha_{\mathrm{M} \text {-W }}\right)$ given by Suzuoki and Epstein (1976):

$10^{3} \ln \alpha_{\mathrm{M}-\mathrm{W}}=-22.4 \times 10^{6} \mathrm{~T}^{-2}+26.3+\left(2 \mathrm{X}_{\mathrm{Al}}-4 \mathrm{X}_{\mathrm{Mg}}-\right.$ $\left.68 * \mathrm{X}_{\mathrm{Fe}}\right) * *$ where

$* \mathrm{X}_{\mathrm{Fe}}=\mathrm{Fe}^{2+} /\left(\mathrm{Fe}^{2+}+\mathrm{Mg}\right)$

$* * \mathrm{X}=$ the atomic fraction of $\mathrm{Al}, \mathrm{Mg}$, and $\mathrm{Fe}$

The $\mathrm{X}_{\mathrm{Fe}}$ values of the minerals in the ilmeniteseries rocks are generally $0.35-0.45$ (hornblende) and $0.40-0.50$ (biotite), and throughout the mass the values are nearly constant. The $\sigma D$ values are distributed in a narrow range but sometimes they are a little spread. By contrast the $\sigma D$ values in the magnetite-series rocks are 0.20-0.35 (hornblende) and 0.25-0.40 (biotite). In addition, the values are larger for the earlier stage rocks and smaller for the later stage rocks, and the $\sigma \mathrm{D}$ values become lower from the earier to the later stage rocks. These dlfferences in the $\sigma \mathrm{D}-\mathrm{X}_{\mathrm{Fe}}$ diagram between the ilmenite- and magnetite-series rocks are considered to be dependent on the difference in intrusive conditions; e.g. the magnetite-series magma is characterized by high oxygen fugacity and open system conditions for aqueous fluid, and the ilmenite-series magma by relatively lower oxygen fugacity presumably due to closed system conditions (Kuroda et al. 1989, Kuroda 1990).

The $\sigma D$ value of water participating in the formation of hornblende and biotite is variable ( -30 to $-90 \%$ ) in the Japanese Cretaceous granitic masses regardless of the rock-series. The $\sigma \mathrm{D}$ value of the water has been estimated on the basis of the Suzuoki-Epstein's equation with the assumption that the settling temperature of $\mathrm{D} / \mathrm{H}$ ratios of the minerals is $600-650{ }^{\circ} \mathrm{C}$. In some cases, the estimated $\sigma D$ values of the water are nearly constant throughout the granitic body, but occasionally they are scattered within the range of $20-40 \%$ even in the same granitic body.

The $\sigma \mathrm{D}-\mathrm{X}_{\mathrm{Fe}}$ relationship of coexisting hornblende and biotite from rapakivi granites in Finland was first determined by Kuroda et al. (1978). The pattern was quite different from those of the Japanese granitic rocks. The $\sigma \mathrm{D}$ value of hornblende is much lower ( -100 to $-120 \%$ ) than that of biotite ( -65 to $-80 \%$ ), though the $\mathrm{X}_{\mathrm{Fe}}$ values of both minerals are nearly the same with high values (0.8-0.9). A few examples of rapakivi granites from the U.S.A. (Pikes Peak batholith) and China (north of Beijing) were also examined and found to be similar to those of Finnish rapakivi (Kuroda et al. 1985 and Kuroda in prep.). Furthermore, the $\sigma D-X_{\mathrm{Fe}}$ relationship between amphibole and phlogopite from the mica nodules of South African kimberlite was also the same (low $\sigma D$ of amphibole and high $\sigma D$ of phlogopite) as that of rapakivi granite in spite of the very low $\mathrm{X}_{\mathrm{Fe}}$ values of both minerals (Kuroda et al. 1975).

It is noteworthy that the water $(\mathrm{OH})$ content (calculated as $\mathrm{H}_{2} \mathrm{O}$ ) of the hydrous minerals, especially amphibole, from rapakivi granites and also from kimberlite nodules is significantly low (commonly amphibole 1.5-1.7 wt\%, mica 2.7- 3.2 wt $\%$ ) compared with those of Japanese granitic rocks (commonly hornblende $1.9-2.1 \mathrm{wt} \%$, biotite 3.7- $3.9 \mathrm{wt} \%$ ).

Because the $\sigma \mathrm{D}-\mathrm{X}_{\mathrm{Fe}}$ relationships between the Japanese granitic rocks and rapakivi granites were known to be remarkably different, we wanted to extend our study to various granitic rocks of the Svecofennian belt. We collected samples from several rapakivi granite masses in Finland, as well as from the Revsund, Vänge, and Uppsala granites in Sweden and then the granitic rocks around Turku in Finland. Hornblende and biotite were separated from these rock samples and subjected to the determinations of $\sigma \mathrm{D}$, water $(\mathrm{OH})$ content and chemical composition. Based on the data obtained, we will discuss the differences in $\sigma D-X_{\mathrm{Fe}}$ 


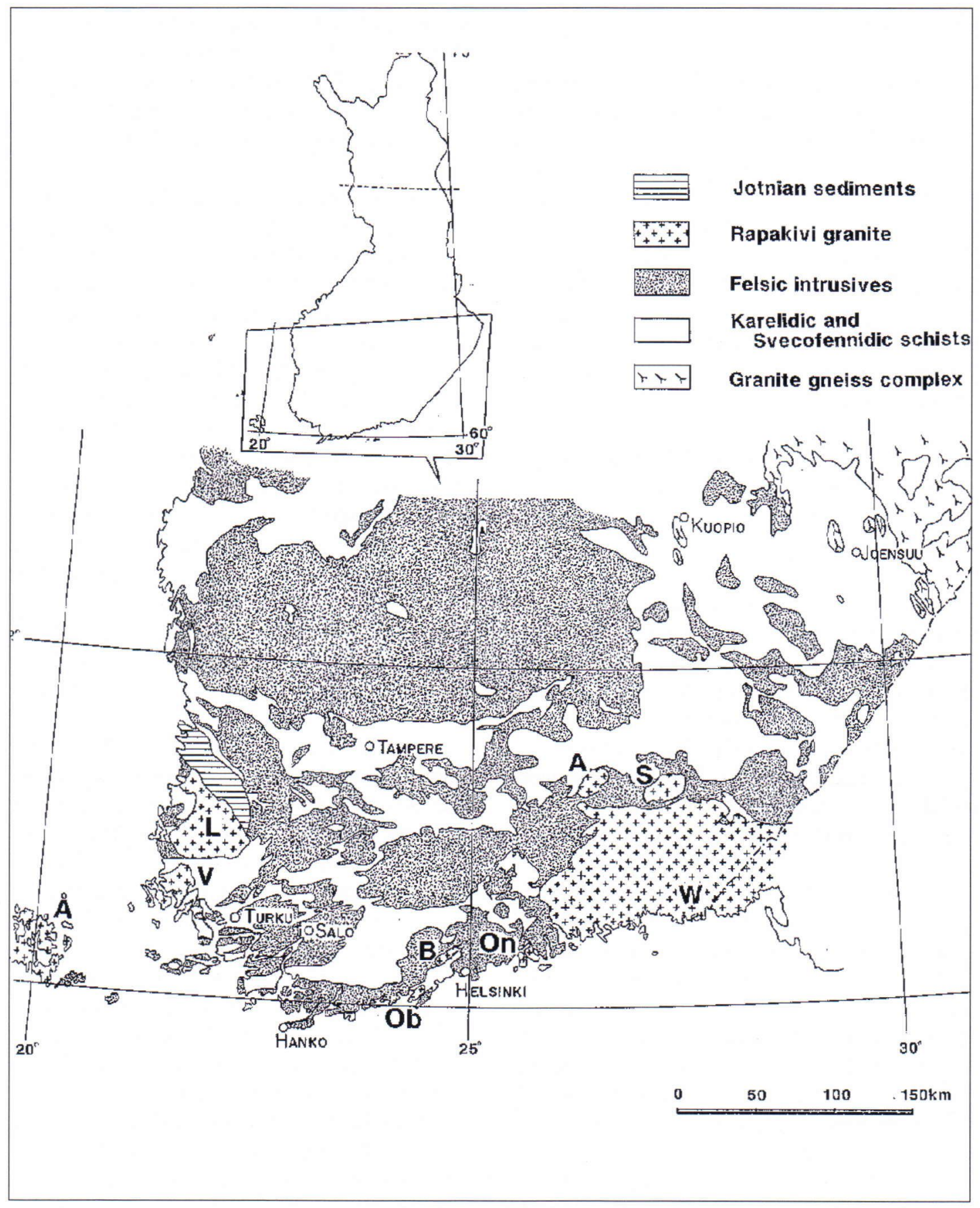

Fig. 1. Distribution of rapakivi granite batholiths and stocks in southern Finland. $W=$ Wiborg, $S=$ Suomenniemi, $A=$ Ahvenisto, On = Onas, $B=$ Bodom, $O B=$ Obnäs, $L=$ Laitila, $V=$ Vehmaa and $\AA=\AA$ Aland. 
relationships between Japanese island arc granitic rocks, Svecofennian granitic rocks and rapakivi granites in terms of the differences in the behavior of water or hydroxyl in the magmas.

\section{GEOLOGY AND $\sigma D-X_{\mathrm{Fe}}$ RELATIONSHIP OF HORNBLENDE AND BIOTITE}

\section{Rapakivi granites}

There are four large rapakivi granite batholiths (Wiborg, Laitila, Vehmaa and Alland) and several smaller stocks and batholiths such as Onas, Bodom and Obbnäs outcropping in southern Finland (Haapala and Rämö 1990, Fig. 1). The U-Pb ages of zircon from these rocks are 1.65 to $1.54 \mathrm{Ga}$ (Wiborg 1.65-1.63 Ga, Vehmaa 1.59 Ga, Åland 1.59-1.57
Ga and Laitila 1.57-1.54 Ga; Vaasjoki 1977, Vaasjoki et al. 1991). The batholiths consist of several slightly different granitic subfacies which differ from each other in content of mafic minerals, grain size, texture of feldspar ovoids etc. Therefore, we collected a large number of specimens from various subfacies throughout the batholiths of Wiborg (Fig. 2), Vehmaa and Laitila (Fig. 3).

The Wiborg batholith is composed of several rock facies as follows (Simonen and Vorma, 1969):

Wiborgite - coarse-grained porphyritic granite with mantled feldspar (typical rapakivi texture). The most abundant rock facies (more than $75 \%$ of the areal distribution) in the Wiborg rapakivi batholith in Finland.

Dark-colored wiborgite - plagioclase and hornblende contents are higher and potash feldspar content is lower than in the normal wiborgite. Also

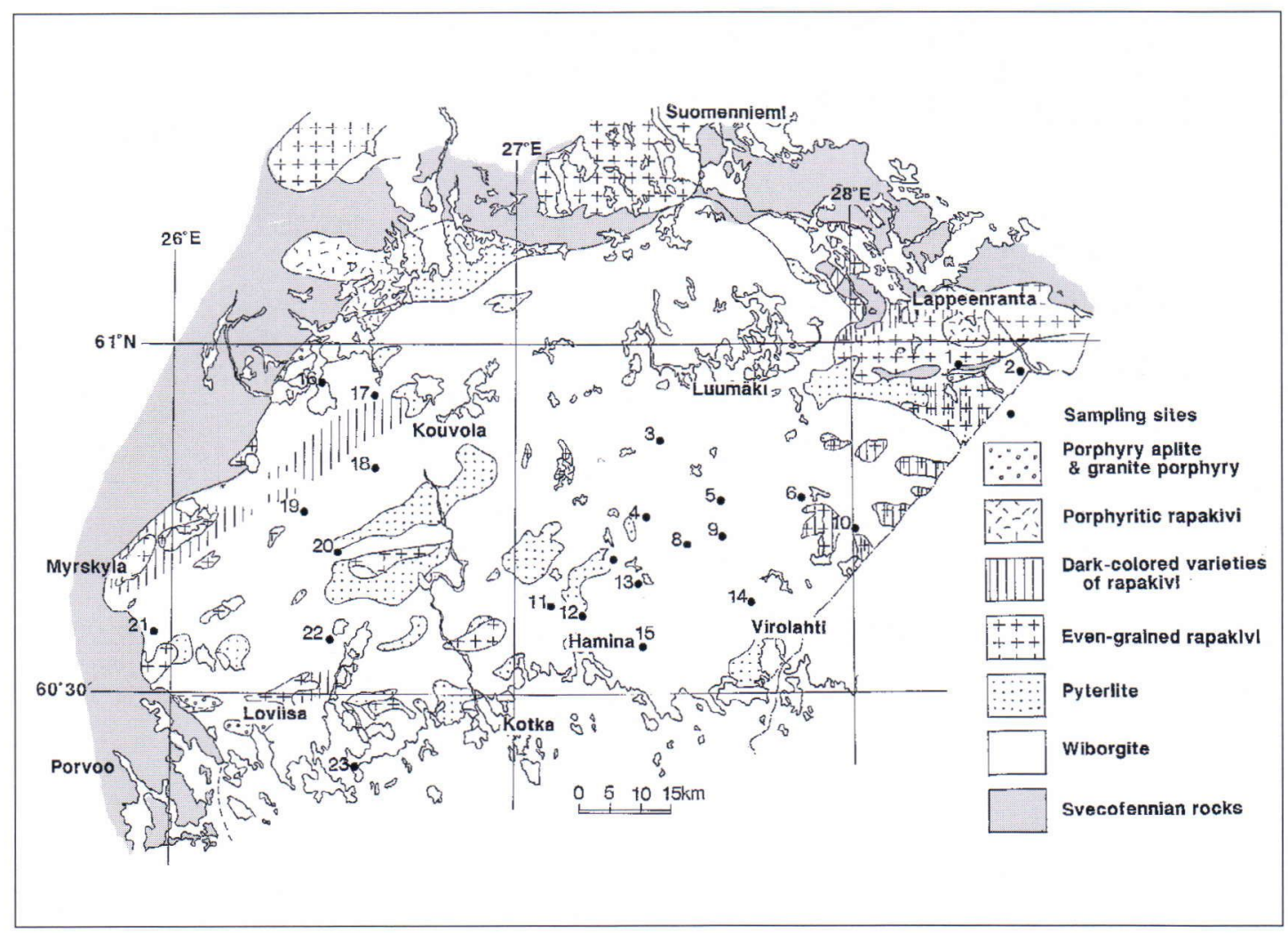

Fig. 2. Geological map and sampling sites of the Wiborg batholith. Map is simplified from Härme (1980). 


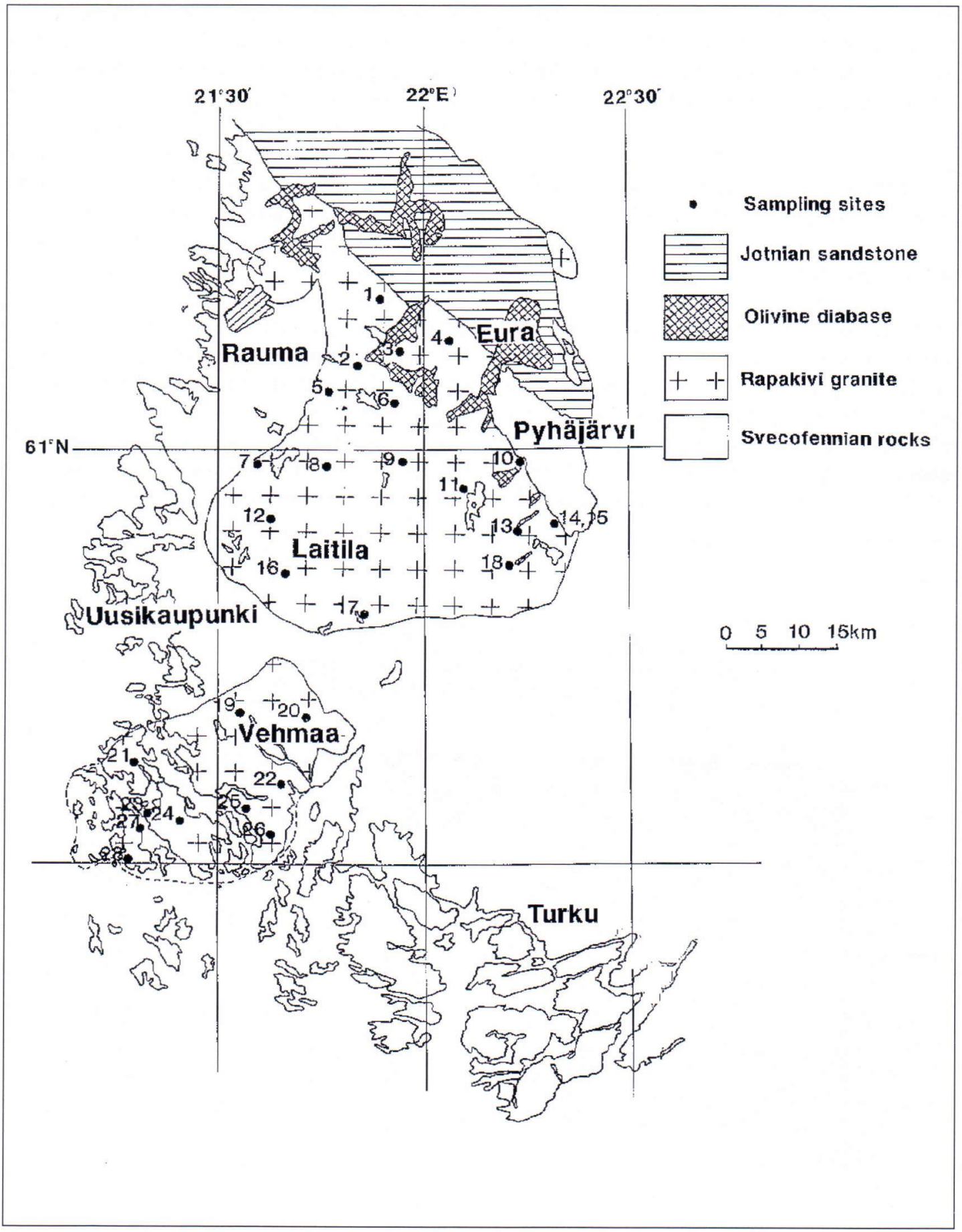

Fig. 3. Geological map and sampling sites of the Laitila and Vehmaa batholiths. Map is simplified from Härme (1958) and Vorma (1976.). 
characterized by mantled feldspar.

Pyterite - coarse-grained extremely porphyritic granite with large ovoidal potash feldspar. Mantled feldspar are also found sporadically. Plagioclase content is lower than in wiborgite and mafic minerals are fewer. Usually only biotite is present.

Even-grained rapakivi - medium to coarsegrained potash feldspar, rich granite. Usually redcolored, but sometimes white colored topaz-bearing variety is included.

Dark-colored even-grained rapakivi - medium to coarse-grained and mostly even-grained with some porphyritic varieties. An extremly mafic rich one called tirilite contains olivine, monoclinic pyroxene together with hornblende, biotite and grunerite.

Porphyritic rapakivi - characterized by abundant angular phenocrysts of potash feldspar without oligoclase mantle.

There are other minor varieties in the Wiborg batolith such as porphyritic aplite, quartz porphyry and granite porphyry.

The Laitila batholith is composed of normal Laitila rapakivi, granite porphyry, biotite rapakivi, the Ytö and Suutila granites, and the Eurajoki complex (Vorma 1976). The normal Laitila rapakivi, a coarse-grained porphyritic granite, is the major rock facies of the Laitila batholith. Large ovoidal potash feldspar (pyterite texture) is common and the wiborgite texture with thin plagioclase mantle is poorly developed. Content of mafic minerals varies widely.

The Vehmaa rapakivi a is rather homogeneous coarse-grained hornblende-biotite granite which

Table 1. Analytical results of biotites and hornblendes of the Wiborg batholith, Southeast Finland.

\begin{tabular}{|c|c|c|c|c|c|c|c|c|}
\hline \multicolumn{9}{|c|}{$=$} \\
\hline \multirow{2}{*}{\multicolumn{2}{|c|}{ Sample No. }} & \multicolumn{3}{|c|}{ Biotite } & \multicolumn{3}{|c|}{ Hornblende } & \multirow{2}{*}{ Remarks } \\
\hline & & $\mathrm{H}_{2} \mathrm{O}(w t \%)$ & $\delta D(\%)$ & $\mathrm{X}_{\mathrm{Fe}}$ & $\mathrm{H}_{2} \mathrm{O}(\mathrm{wt} \%)$ & $\delta D(\%)$ & $\mathrm{X}_{\mathrm{Fe}}$ & \\
\hline 1 & 86071703 & 3.07 & -64.1 & 0.84 & 1.48 & -96.6 & 0.86 & Dark-colored even-grained rapakivi \\
\hline 2 & 86071702 & 3.00 & -84.1 & 0.86 & 1.26 & -109.9 & 0.88 & Wiborgite \\
\hline 3 & 86072707 & 3.05 & -84.3 & 0.88 & 1.46 & -122.0 & 0.88 & " \\
\hline 4 & 86072705 & 2.58 & -88.4 & 0.90 & 1.24 & -122.7 & 0.89 & Dark-colored wiborgite \\
\hline 5 & 86072711 & 3.30 & -88.3 & 0.87 & 1.30 & -94.1 & 0.88 & Wiborgite \\
\hline 6 & 86073008 & 3.49 & -85.8 & 0.88 & 1.48 & -106.4 & 0.85 & " \\
\hline 7 & 86072703 & 3.11 & -81.5 & 0.90 & 1.67 & -104.6 & 0.87 & $"$ \\
\hline 8 & 86073011 & 3.38 & -80.3 & 0.89 & 1.38 & -101.5 & 0.85 & $"$ \\
\hline 9 & 86073010 & 2.89 & -81.5 & 0.89 & 1.38 & -107.8 & 0.85 & Dark-colored wiborgite \\
\hline 10 & 86073005 & 3.17 & -80.0 & 0.87 & 1.21 & -112.3 & 0.86 & Wiborgite \\
\hline 11 & 86072805 & 3.04 & -84.4 & 0.88 & 1.58 & -104.5 & 0.86 & $"$ \\
\hline 12 & 86072701 & 2.59 & -91.5 & 0.89 & 1.44 & -105.4 & 0.88 & $"$ \\
\hline 13 & $86073013 \mathrm{~A}$ & 3.19 & -92.2 & 0.87 & 1.49 & -120.9 & 0.85 & $"$ \\
\hline 14 & 86072713 & 2.74 & -98.6 & 0.91 & 1.57 & -109.4 & 0.89 & $"$ \\
\hline 15 & 86072716 & 3.31 & -78.9 & 0.88 & 1.39 & -98.6 & 0.88 & $"$ \\
\hline 16 & 86090608 & 2.90 & -95.6 & 0.84 & 1.23 & -117.3 & 0.86 & Dark-colored wiborgite \\
\hline 17 & 86090607 & 2.97 & -95.3 & 0.91 & 1.51 & -119.9 & 0.90 & Coarse-grained wiborgite \\
\hline 18 & 86090606 & $6.60 *$ & -61.0 & 0.85 & 1.80 & -83.8 & 0.83 & Wiborgite \\
\hline 19 & 86090610 & 2.79 & -92.6 & 0.91 & 1.43 & -112.7 & 0.90 & $"$ \\
\hline 20 & 86090604 & $4.28 *$ & -64.3 & 0.86 & 2.09 & -87.1 & 0.82 & $"$ \\
\hline 21 & 86090815 & 3.74 & -85.7 & 0.88 & 1.35 & -120.1 & 0.85 & $"$ \\
\hline 22 & 86090602 & 3.27 & -84.0 & 0.88 & 1.88 & -99.8 & 0.83 & $"$ \\
\hline 23 & 86090808 & 3.45 & -90.0 & 0.91 & 1.28 & -115.4 & 0.84 & Hornblende-rich rapakivi in wiborgite \\
\hline
\end{tabular}


varies from even-grained to porphyritic and darkto light-coloured.

Twenty three samples from the Wiborg batholith, 18 samples from normal Laitila rapakivi and 10 samples from the Vehmaa batholith were analyzed.

The $\sigma \mathrm{D}$ and $\mathrm{X}_{\mathrm{Fe}}$ values of hornblende and biotite from these specimens are presented in Tables 1 and 2 and the $\sigma \mathrm{D}-\mathrm{X}_{\mathrm{Fe}}$ relationships of coexisting hornblende and biotite are shown in Figs $4 a$ and $4 b$. The pattern is the same as that reported previously (Kuroda et al. 1978). SD values of hornblende are definitely lower ( -85 to $-120 \%$ o) than those of coexisting biotite (-60 to $-105 \%$ ), the difference being 15-30\% 0 . The $\mathrm{X}_{\mathrm{Fe}}$ values of both minerals are high and close to each other (0.8-0.9), but usually those of biotite are a little higher $(0.02$ higher on average) than those of hornblende. The water contents of both minerals are low, especially for hornblende (the average hornblende $1.51 \mathrm{wt} \%$, biotite $3.11 \mathrm{wt} \%)$. In this case, the fluorine contents are high, especially higher in hornblende (0.4-1.1 $\mathrm{wt} \%$ ) than biotite $(0.2-0.8 \mathrm{wt} \%)$. It is considered to compensate for the deficiency of hydroxyl content. For the Åland batholith and other small plutons it

Table 2. Analytical results of biotites and hornblendes of the Laitila and Vehmaa batholith, Southwest Finland.

\begin{tabular}{|c|c|c|c|c|c|c|c|c|}
\hline \multirow{2}{*}{\multicolumn{2}{|c|}{ Sample No. }} & \multicolumn{3}{|c|}{ Biotite } & \multicolumn{3}{|c|}{ Hornblende } & \multirow{2}{*}{ Remarks } \\
\hline & & $\mathrm{H}_{2} \mathrm{O}(w t \%)$ & $\delta D(\%)$ & $\mathrm{X}_{\mathrm{Fe}}$ & $\mathrm{H}_{2} \mathrm{O}(\mathrm{wt} \%)$ & $\delta D(\%)$ & $\mathrm{X}_{\mathrm{Fe}}$ & \\
\hline \multicolumn{9}{|c|}{ Laitila massif } \\
\hline 1 & 86080902 & 2.96 & -100.0 & 0.85 & 1.52 & -113.9 & 0.85 & Coarse-grained porphyritic rapakivi \\
\hline 2 & 86080516 & 2.53 & -75.4 & 0.87 & 1.55 & -111.3 & 0.83 & Dark-colored rapakivi \\
\hline 3 & 86080702 & 2.79 & -86.9 & 0.90 & 1.88 & -121.7 & 0.85 & Coarse-grained ovoidal rapakivi \\
\hline 4 & 86080701 & 2.43 & -96.1 & 0.86 & 1.37 & -120.9 & 0.85 & Dark-colored porphyritic rapakivi \\
\hline 5 & 86080703 & 3.05 & -81.7 & 0.87 & 1.60 & -99.4 & 0.84 & Coarse-grained ovoidal rapakivi \\
\hline 6 & 86080517 & 3.03 & -80.8 & 0.87 & 1.55 & -113.2 & 0.84 & Light-colored rapakivi \\
\hline 7 & 86080510 & 2.86 & -76.8 & 0.87 & 1.67 & -101.6 & 0.83 & Coarse-grained rapakivi \\
\hline 8 & 86080706 & 3.26 & -78.1 & 0.88 & 1.40 & -110.2 & 0.83 & Coarse-grained ovoidal rapakivi \\
\hline 9 & 86080417 & 2.11 & -103.6 & 0.83 & 1.30 & -113.4 & 0.83 & Coarse-grained rapakivi \\
\hline 10 & 86080401 & 3.49 & -84.0 & 0.89 & 1.43 & -118.3 & 0.88 & Coarse-grained ovoidal rapakivi \\
\hline 11 & 86080602 & 2.64 & -78.3 & 0.85 & - & -105.9 & 0.83 & Coarse-grained rapakivi \\
\hline 12 & 86080508 & 3.48 & -87.0 & 0.90 & 1.44 & -108.9 & 0.87 & Coarse-grained ovoidal rapakivi \\
\hline 13 & 86080711 & 2.57 & -93.5 & 0.87 & 1.38 & -125.9 & 0.84 & Light-colored rapakivi \\
\hline 14 & $86080404 \mathrm{~A}$ & 2.35 & -86.9 & 0.84 & 1.50 & -121.1 & 0.87 & Coarse-grained rapakivi \\
\hline 15 & $86080404 \mathrm{~B}$ & 2.08 & -106.5 & 0.86 & 1.34 & -122.7 & 0.87 & Dark-colored rapakivi \\
\hline 16 & 86080505 & 3.31 & -86.3 & 0.91 & 1.49 & -106.0 & 0.83 & Coarse-grained ovoidal rapakivi \\
\hline 17 & 86080413 & 3.10 & -70.1 & 0.89 & 1.42 & -95.8 & 0.87 & Coarse-grained rapakivi \\
\hline 18 & 86080710 & 3.54 & -81.1 & 0.89 & 1.58 & -109.8 & 0.87 & Light-colored rapakivi \\
\hline \multicolumn{9}{|c|}{ Vehmaa massif } \\
\hline 19 & $86080609 A$ & - & -75.7 & 0.90 & 1.68 & -109.8 & 0.87 & Porphyritic rapakivi \\
\hline 20 & 86080607 & 3.12 & -85.1 & 0.91 & 1.58 & -107.8 & 0.86 & Porphyritic rapakivi \\
\hline 21 & 86080617 & 3.34 & -91.5 & 0.91 & 1.38 & -107.7 & 0.88 & Coarse-grained rapakivi \\
\hline 22 & 86080621 & 3.24 & -76.2 & 0.92 & 1.55 & -90.2 & 0.88 & " \\
\hline 23 & 86080616 & 2.67 & -93.0 & 0.90 & 1.39 & -112.6 & 0.89 & Dark-colored coarse-grained rapakivi \\
\hline 24 & 86030615 & 3.23 & -86.6 & 0.89 & 1.48 & -112.7 & 0.87 & " \\
\hline 25 & 86080613 & 3.10 & -92.6 & 0.92 & 1.58 & -120.2 & 0.88 & Coarse-grained rapakivi \\
\hline 26 & 86080620 & 3.03 & -73.4 & 0.92 & 1.53 & -104.4 & 0.88 & " \\
\hline 27 & 86081502 & 2.73 & -82.0 & 0.92 & 1.46 & -104.0 & 0.89 & Dark-colored rapakivi \\
\hline 28 & 86081501 & 3.45 & -77.4 & 0.89 & 1.89 & -94.5 & 0.88 & Light-colored even-grained rapakivi \\
\hline
\end{tabular}




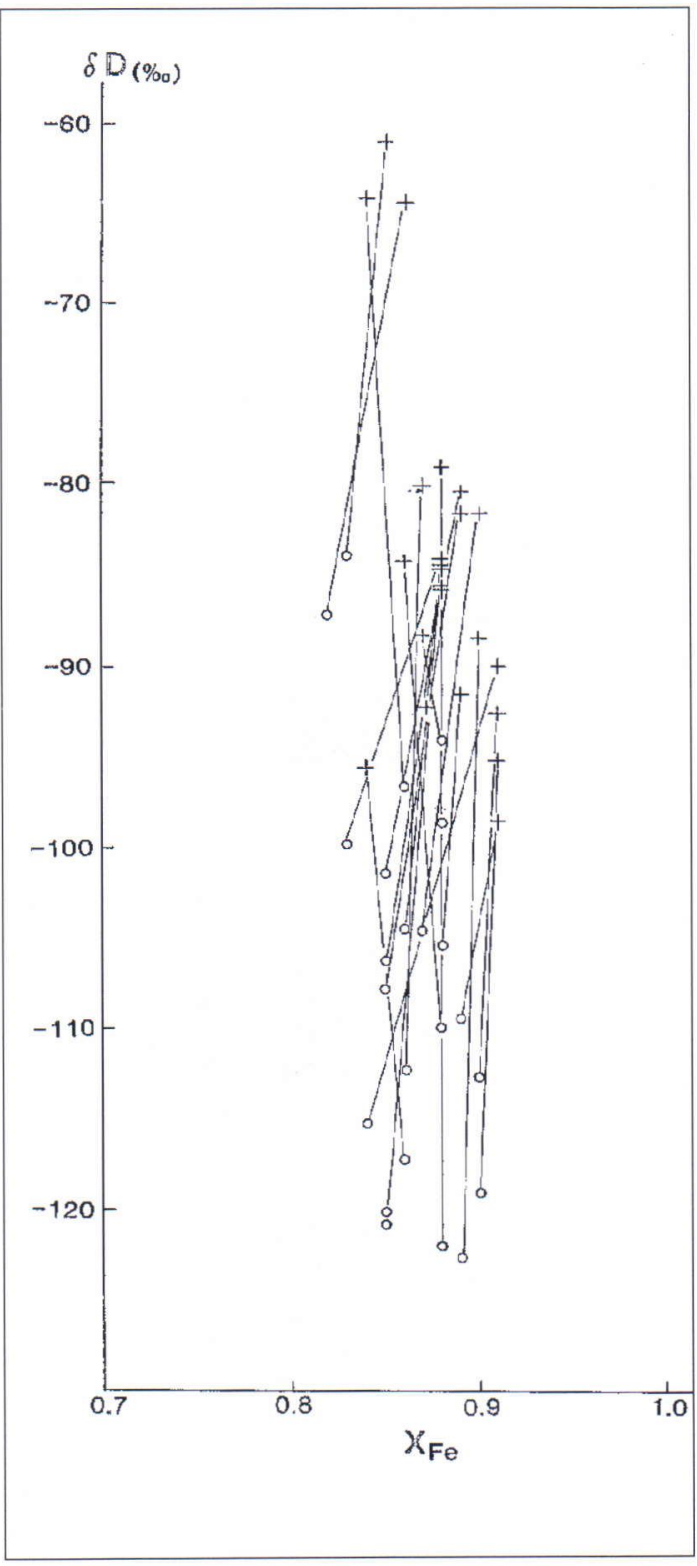

was difficult to get fresh coexisting hornblende and biotite, because hydrothermal mineralizations of a later stage are common throughout the pluton. In such a case, chloritization of the minerals usually changes the original $\sigma D$ values of hornblende and biotite, especially biotite. However, the $\sigma \mathrm{D}$ and $\mathrm{X}_{\mathrm{Fe}}$ values of a few hornblende and biotite, which were free from the chloritization, are close to those

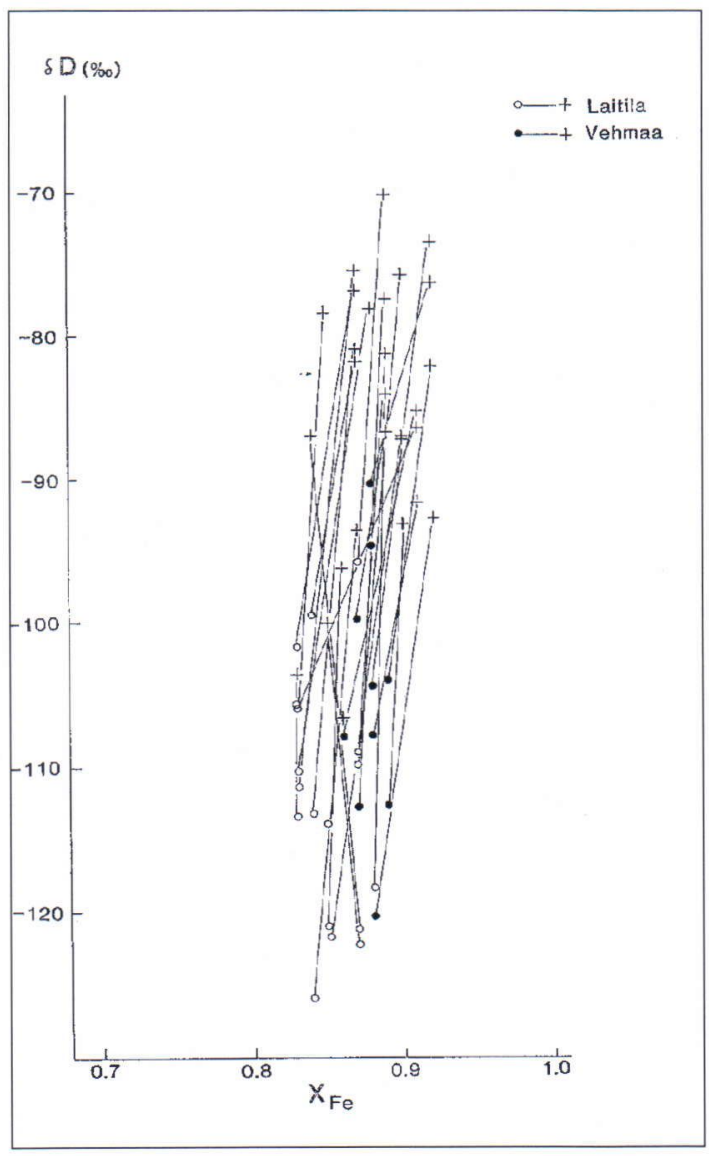

Fig. 4. Relationship between $\sigma D$ and $X_{F e}$ for biotite(cross) and hornblende(circle) from the rapakivi batholiths.

$A=$ Wiborg batholith (left), $B=$ Laitila and Vehmaa batholiths (above). of hornblende or biotite in the three batholiths mentioned above. Therefore, the $\sigma \mathrm{D}-\mathrm{X}_{\mathrm{Fe}}$ relationships between hornblende and biotite are fundamentally the same for all the rapakivi granites.

\section{Revsund granite}

In central Sweden there are coarse grained 


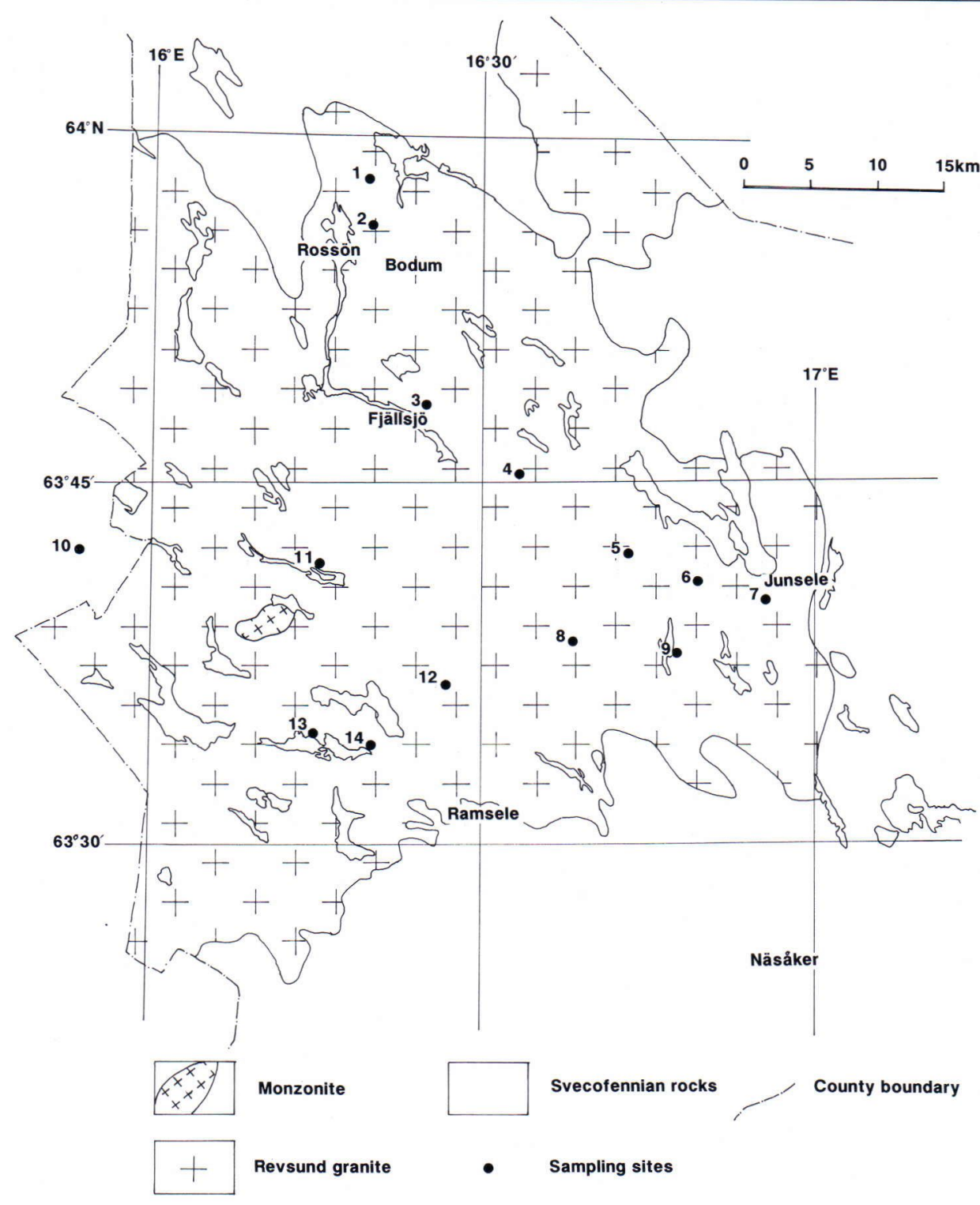

Fig. 5. Geological map and sampling sites of the Revsund granite batholith in the western part of Västernorland County. Map is simplified from Lundqvist (1987).

porphyritic granites called the Revsund granite, which have been considered to be serorogenic to post-orogenic intrusions not having suffered dislocation metamorphism (Lundqvist 1979). According to Welin et al. (1971, 1977) the Rb-Sr whole rock age is $1745-1735 \mathrm{Ma}$. The rock facies are slightly different from place to place. In some places the rocks resemble the Finnish rapakivi granite.

The areal distribution of the Revsund granite has recently been mapped in the Västernorrland County, central Sweden by Lundqvist (1987). The 
main rock-type is small- to coarse-porphyritic granite (quartz-monzonite to granitic composition) with minor amounts of granodiorite, quartz-monzonite, diorite to tonalite, and trondhjemite. The Revsund granite in the western part of the area mapped in Fig. 5 was investigated in detail by Perrson (1978).

The authors divided the Revsund granite into three rock-types according to their mineral compositions and areal distribution, i.e. 1) coarseporphyritic hornblende-biotite granite (pinkish greycolored ovoidal and/or tabular potash feldspar) (Rossön type), 2) extremely porphyritic cummingtonite-hornblende-biotite granite (pinkish grey to greyish white-colored potash feldspar) (Junsele type) and 3) small porphyritic cummingtonite-hornblende -biotite granodiorite (grey to white-colored potash feldspar) (Ramselesjön type).

Mantled feldspar ovoids consisting of perthitic microcline rimmed with plagioclase and bluish quartz grains are not uncommon. Hornblende is usually zoned with a brownish core surrounded by a greenish part. Cummingtonite occurs in the centre of brownish hornblende. It was difficult to separate completely cummingtonite and hornblende, so the purities of hornblende are given in Table 3 in volume percentage.

Fourteen samples of the Revsund granite were analyzed and the sample sites are shown in Fig. 5. The $\sigma \mathrm{D}, \mathrm{X}_{\mathrm{Fe}}$ values and water contents of coexisting

Table 3. Analytical results of biotites and amphiboles of the Revsund granites, central Sweden.

\begin{tabular}{|c|c|c|c|c|c|c|c|c|}
\hline \multirow{2}{*}{\multicolumn{2}{|c|}{ Sample No. }} & \multicolumn{3}{|c|}{ Biotite } & \multicolumn{3}{|c|}{ Amphibole } & \multirow[b]{2}{*}{$\mathrm{R}_{\mathrm{Ho}}(\%)$} \\
\hline & & $\mathrm{H}_{2} \mathrm{O}(\mathrm{wt} \%)$ & $\delta \mathrm{D}(\%)$ & $\mathrm{X}_{\mathrm{Fe}}$ & $\mathrm{H}_{2} \mathrm{O}(w \mathrm{t} \%)$ & $\delta \mathrm{D}(\%)$ & $x_{\mathrm{Fe}}$ & \\
\hline \multicolumn{9}{|c|}{ Rossön type } \\
\hline 1 & 88082407 & 3.81 & -76.9 & 0.76 & 1.76 & -88.7 & 0.79 & 98 \\
\hline 2 & 88082408 & 3.92 & -76.0 & 0.78 & 1.82 & -112.7 & 0.77 & 98 \\
\hline 3 & 88082406 & 3.49 & -77.4 & 0.76 & 1.74 & -87.5 & 0.77 & 98 \\
\hline \multicolumn{9}{|c|}{ Junsele type } \\
\hline 4 & 88082405 & 3.37 & -73.2 & 0.75 & 1.68 & -86.0 & 0.73 & 68 \\
\hline 5 & 88082404 & 3.28 & -73.0 & 0.77 & 1.76 & -90.7 & 0.73 & 76 \\
\hline 6 & 88082403 & 3.88 & -68.5 & 0.76 & 1.78 & -105.0 & 0.75 & 72 \\
\hline 7 & 88082402 & 3.72 & -81.9 & 0.77 & 2.78 & -99.0 & 0.73 & 71 \\
\hline 8 & 88082501 & 3.50 & -71.5 & 0.76 & 1.77 & -91.5 & 0.74 & 67 \\
\hline 9 & 88082401 & 3.41 & -69.0 & 0.75 & 1.77 & -89.8 & 0.73 & 84 \\
\hline \multicolumn{9}{|c|}{ Ramselesjon type } \\
\hline 10 & 88082508 & 3.55 & -76.5 & 0.77 & 1.89 & -103.7 & 0.75 & 69 \\
\hline 11 & 88082509 & 3.00 & -81.5 & 0.77 & 1.66 & -94.5 & 0.77 & 68 \\
\hline 12 & 88082502 & 3.08 & -74.3 & 0.76 & 1.68 & -75.0 & 0.74 & 79 \\
\hline 13 & 88082505 & 3.89 & -70.7 & 0.77 & 1.99 & -79.3 & 0.72 & 90 \\
\hline 14 & 88082504 & 3.37 & -77.7 & 0.75 & 2.02 & -85.3 & 0.73 & 74 \\
\hline
\end{tabular}


amphibole and biotite are shown in Table 3. As seen in Fig. 6 , the $\sigma \mathrm{D}-\mathrm{X}_{\mathrm{Fe}}$ relatlonships between coexisting hornblende and biotite are slmilar to those of rapakivi granites, but the $\mathrm{X}_{\mathrm{Fe}}$ values of these minerals are a little lower (0.7-0.8) than in rapaklvi. The $\mathrm{X}_{\mathrm{Fe}}$ values of biotite are also a little higher ( 0.02 on average) than those of hornblende as in the case of rapakivl granite. The $\sigma D$ values of the amphibole samples are sometimes higher than $-90 \%$, though the $\sigma \mathrm{D}$ value of hornblende of rapakivi granites are lower. The water $(\mathrm{OH})$ contents of amphibole (average $1.82 \mathrm{wt} \%$ ) and biotite (average $3.51 \mathrm{wt} \%$ ) are not as low as those of rapakivi granite. Fluorine contents are a little lower than those of rapakivi (i.e. hornblende 0.6-0.2 wt\%, blotite $0.7-0.3 \mathrm{wt} \%$ ).

In this case, it must be noticed that the $\sigma \mathrm{D}-\mathrm{X}_{\mathrm{Fe}}$ relationships of cummingtonite or anthophyllite are different from those of Ca-bearing amphiboles as mentioned before (Kuroda 1990). In the $\sigma D-X_{\mathrm{Fe}}$ diagrams of hornblende and biotite, the $\mathrm{X}_{\mathrm{Fe}}$ value is calculated for the octahedral (six-coordinated) cation sites. However, cummingtonite and anthophylllte contain $\mathrm{Fe}$ and $\mathrm{Mg}$ not only in the six-coordinated site but also in the eight- coordlnated site, and $\mathrm{Fe}^{2+}$ is much enriched in the latter (Ghose 1965). Therefore, $\sigma D-X_{\mathrm{Fe}}$ relationships between cummingtonite or anthophyllite and biotite are somewhat different from those of hornblende and biotite (Kuroda 1990). However, in the case of Revsund granite this effect is not remarkable, because in the prepared amphibole concentrate the hornblende fraction is overwhelmingly predominant (Table 3 ).

\section{Uppsala and Vänge granites}

The Uppsala granite consists of even- and mediumgrained, grey coloured quartz diorite to granodiorite, mostly tonalite. It intruded synkinematically into the Svecofennian metamorphic belt around Uppsala, varying from massive through weakly foliated to gneissose. Enclaves of metasediments and metavolcanics of various size are also found in the Uppsala granite. Some large ones are shown in Fig. 7.

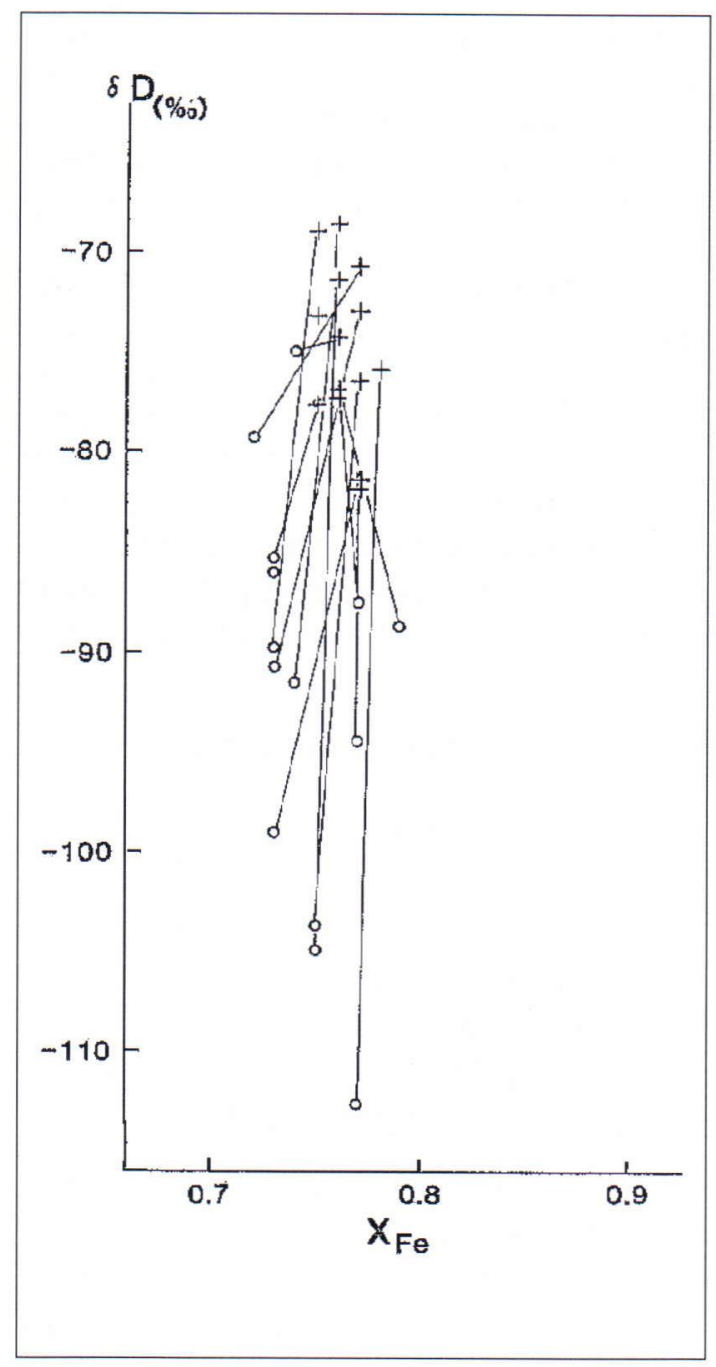

Fig. 6. Relationship between $\sigma D$ and $X_{F e}$ for biotite (cross) and hornblende (circle) from the Revsund granite.

Vänge granite is a medium- to coarse-grained, red-coloured granodiorite to granite, sometimes weakly foliated and/or extremely porphyritic with pink potash feldspar. It intruded into the Uppsala granite. According to Welin et al. (1980), the Rb-Sr isochron age of Uppsala granite is $1830 \pm 13 \mathrm{Ma}$ and that of Vänge granite is $1813^{ \pm} 6 \mathrm{Ma}$.

Seventeen samples from the Uppsala granites and 6 samples from the Vänge granites were 


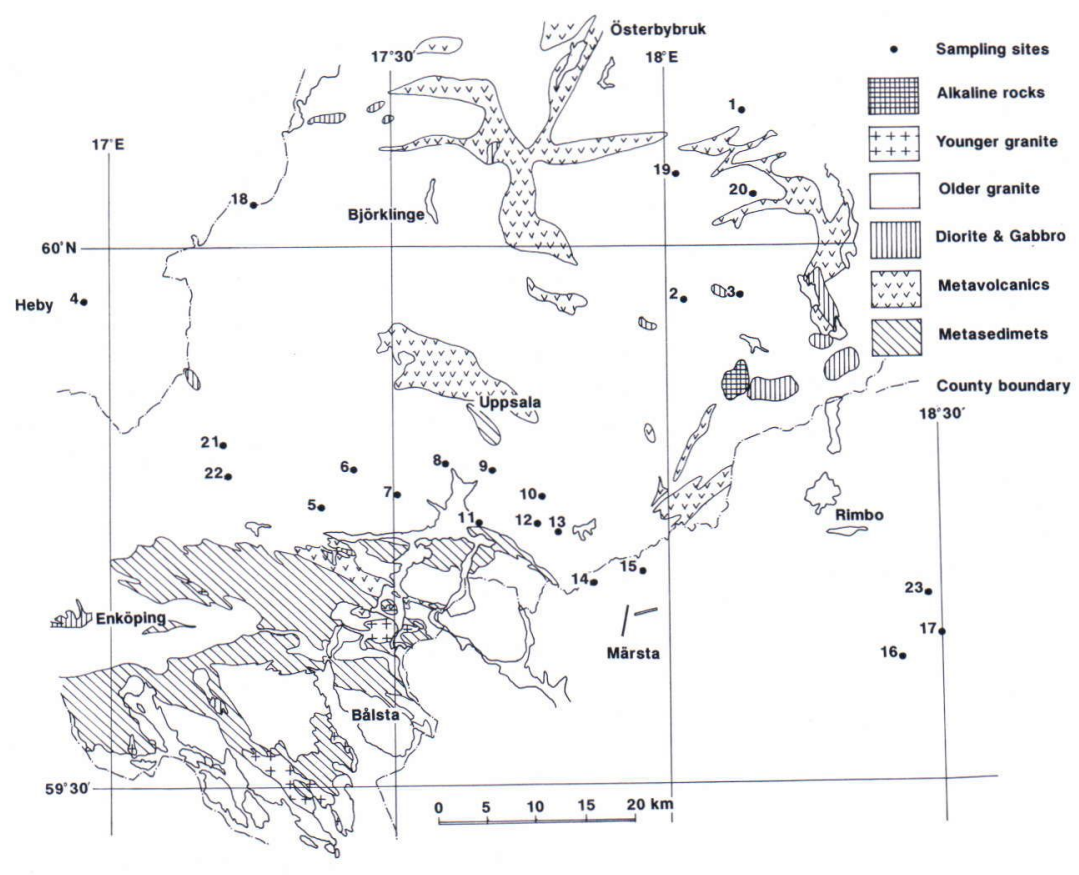

Fig. 7. Geological map and sampling sites of the Uppsala and Vänge granites. Map is simplified from Müller et al. (1983). (Above)

Fig. 8. Relationship between $\sigma D$ and $X_{F e}$ for biotite (cross) and hornblende (circle) from the Uppsala and Vänge granites. (Right)

analyzed and the results are listed in Table 4. The sample sites of these granites are shown in Fig. 7 and the $\sigma \mathrm{D}-\mathrm{XFe}$ relationships are shown in Fig. 8 . The XFe values of hornblende and biotite are scattered from 0.8 to 0.45 and the $\sigma D$ values of both minerals are usually high ( -90 to $-60 \%$ ) though the $\sigma D$ values of Vänge granite of the western part are lower (for hornblende $\sim-110 \%$ ). In the samples with higher XFe values (0.6), the difference in $\sigma D$ values of coexisting hornblende and biotite is larger, and in the sample with lower XFe values the difference is small. The XFe values of biotite are also usually a little higher ( 0.02 on average) than those of coexisting hornblende. It is noteworthy that water contents of the minerals of both granites are little higher (Uppsala; hornblende $2.00 \mathrm{wt} \%$,

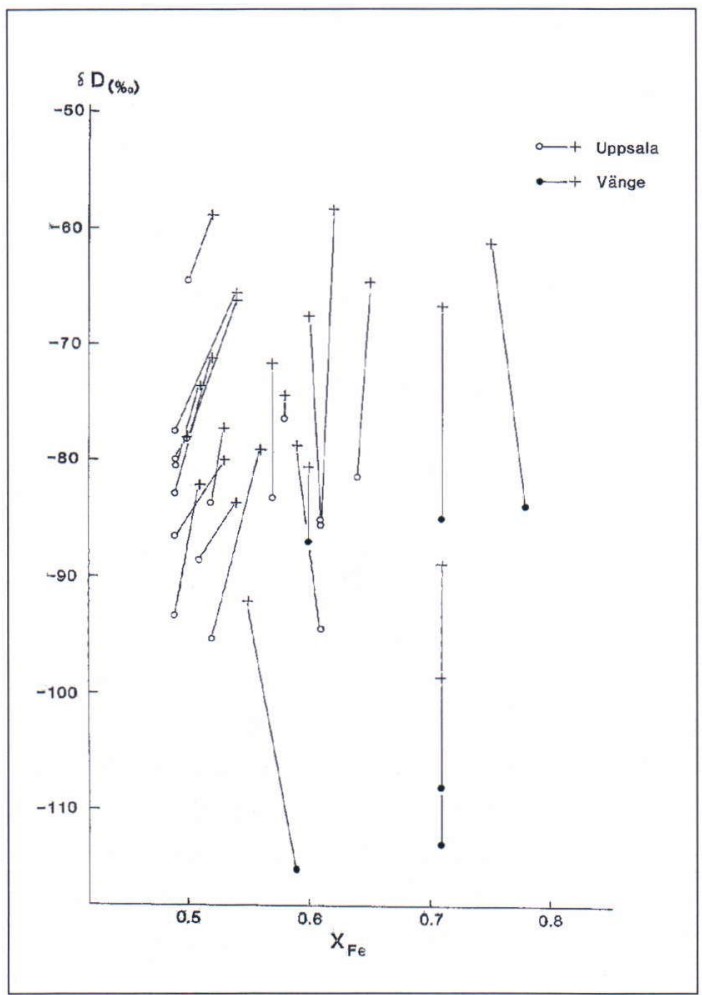


Table 4. Analytical results of biotites and hornblendes of the Uppsala and Vänge granites, Sweden.

\begin{tabular}{|c|c|c|c|c|c|c|c|c|}
\hline \multirow{2}{*}{\multicolumn{2}{|c|}{ Sample No. }} & \multicolumn{3}{|c|}{ Biotite } & \multicolumn{3}{|c|}{ Hornblende } & \multirow{2}{*}{ Remarks } \\
\hline & & $\mathrm{H}_{2} \mathrm{O}(\mathrm{wt} \%)$ & $\delta \mathrm{D}(\%)$ & $\mathrm{X}_{\mathrm{Fe}}$ & $\mathrm{H}_{2} \mathrm{O}(\mathrm{wt} \%)$ & $\delta D(\%)$ & $\mathrm{X}_{\mathrm{Fe}}$ & \\
\hline \multicolumn{9}{|c|}{ Uppsala granite (Tonalite) } \\
\hline 1 & 88090604 & 3.14 & -74.4 & 0.58 & 2.15 & -76.5 & 0.58 & Gneissose tonalite \\
\hline 2 & 88090501 & 4.24 & -77.1 & 0.53 & 2.30 & -83.8 & 0.52 & Medium-grained massive tonalite \\
\hline 3 & 88090603 & 3.44 & -78.7 & 0.59 & 1.97 & -94.5 & 0.61 & Weakly foliated tonalite \\
\hline 4 & 88090806 & 4.43 & -79.0 & 0.56 & 2.18 & -95.3 & 0.52 & Medium-grained massive tonalite \\
\hline 5 & 88090903 & 4.29 & -73.5 & 0.51 & 1.93 & -80.5 & 0.49 & Weakly foliated tonalite \\
\hline 6 & 88090902 & 4.22 & -58.8 & 0.52 & 1.94 & -64.6 & 0.50 & Medium-grained massive tonalite \\
\hline 7 & 88091002 & 4.09 & -65.5 & 0.54 & 2.06 & -77.5 & 0.49 & massive granodiorite \\
\hline 8 & 88091001 & 4.19 & -79.9 & 0.53 & 1.95 & -86.5 & 0.49 & massive tonalite \\
\hline 9 & 88090106 & 3.87 & -82.0 & 0.51 & 1.98 & -93.3 & 0.49 & 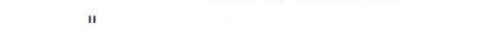 \\
\hline 10 & 88090109 & 4.24 & -66.2 & 0.54 & 1.90 & -78.1 & 0.50 & $"$ \\
\hline 11 & 88090107 & $5.94 *$ & -64.6 & 0.65 & 2.01 & -81.5 & 0.64 & $"$ \\
\hline 12 & 88090108 & 4.41 & -71.1 & 0.52 & 2.03 & -82.9 & 0.49 & $"$ \\
\hline 13 & 88090105 & 3.84 & -83.6 & 0.54 & 1.99 & -88.6 & 0.51 & $"$ \\
\hline 14 & 88090103 & $5.82 *$ & -58.3 & 0.62 & 1.91 & -85.2 & 0.61 & \multirow{2}{*}{$\begin{array}{c}\text { Gneissose tonalite } \\
\text { " }\end{array}$} \\
\hline 15 & 88090104 & 4.18 & -78.0 & 0.50 & 2.02 & -80.0 & 0.49 & \\
\hline 16 & 88090404 & 3.51 & -71.6 & 0.57 & 1.87 & -87.3 & 0.57 & \multirow{2}{*}{$\begin{array}{l}\text { Medium-grained massive tonalite } \\
\text { " }\end{array}$} \\
\hline 17 & 88090403 & 4.33 & -67.5 & 0.60 & 1.85 & -85.6 & 0.61 & \\
\hline \multicolumn{9}{|c|}{ Vunge granite (Red granite) } \\
\hline 18 & 88090802 & 3.51 & -92.0 & 0.55 & 1.90 & -115.0 & 0.59 & Medium-grained porphyritic granodiorite \\
\hline 19 & 88090504 & 3.38 & -80.5 & 0.60 & 1.75 & -86.5 & 0.60 & \multirow{2}{*}{$\begin{array}{l}\text { Porphyritic granite } \\
\qquad "\end{array}$} \\
\hline 20 & 88090502 & 3.99 & -66.6 & 0.71 & 2.11 & -85.0 & 0.71 & \\
\hline 21 & 88090906 & 4.35 & -89.1 & 0.71 & 1.81 & -107.9 & 0.71 & \multirow{2}{*}{$\begin{array}{l}\text { Porphyritic granodiorite } \\
\text { " }\end{array}$} \\
\hline 22 & 88090905 & 4.51 & -98.6 & 0.71 & 1.89 & -112.9 & 0.71 & \\
\hline 23 & 88090402 & 2.91 & -61.2 & 0.75 & 1.86 & -83.3 & 0.78 & Porphyritic granite \\
\hline
\end{tabular}

biotite $4.03 \mathrm{wt} \%$ and Vänge; hornblende $1.88 \mathrm{wt} \%$, biotite $3.77 \mathrm{wt} \%$ on average), especially of the Uppsala granite, than those of the Revsund granite.

\section{The Svecofennian plutonic rocks around Turku}

These granitic rocks crop out in southwestern Finland, and have been studied in detail by Hietanen $(1943,1947)$ and also geochemically by Arth et al.(1978). Hietanen (1947) classified the Svecofennian synorogenic plutonic rocks of the Turku-Kalanti district into three series (e.g. trondhjemite series, charnockite series and the Pöytyä diorites). Simonen (1960) also divided the Svecofennian plutonic rocks of southern Finland into five provinces based on their mineralogical and chemical characteristics; granodiorite, trondhjemite, charnockite, granite and migmatiteforming microcline granite. The last one belongs to the late orogenic intrusive. Simonen's trondhjemiteprovince was represented by the trondhjemite series defined by Hietanen $(1943,1947)$.

The trondhjemite series includes hornblendite, gabbro, diorite, tonalite, trondhjemite and granodiorite. Dominant rock types are even- and medium-grained tonalite and trondhjemite. Hornblende is a rather common mafic constituent except for an acidic variety and potash feldspar is only a minor constituent. These rocks occur as sheet-shaped plutons (Hietanen 1947) or phacoliths (Arth et al. 1978) concordantly in the Svecofennian metamorphic rocks. Foliation and lineation in these 


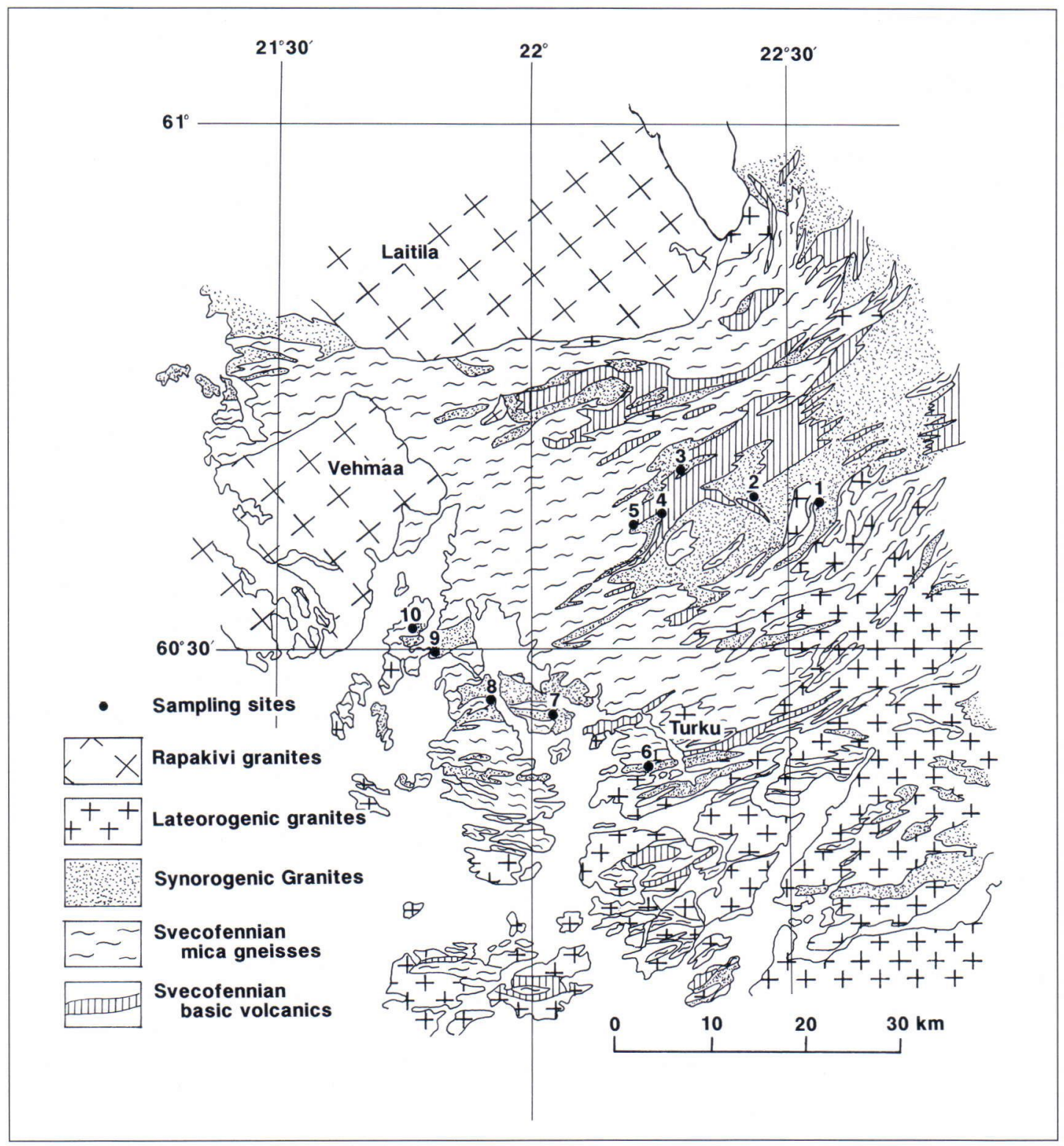

Fig. 9. Geological map and sampling sites of the synorogenic granites around Turku, southwestern Finland. Map is simplified from Härme (1958).

plutonic rocks are commonly developed, especially in the contact zone, and these are parallel with those of the wall rocks. U-Pb zircon age of the trondhjemite suite are about $1890 \mathrm{Ma}$ (Patchett and Kouvo 1986) and $\mathrm{Rb}$-Sr whole rock isochron age is $1934 \pm 52 \mathrm{Ma}$ and the initial ${ }^{87} \mathrm{Sr} /{ }^{86} \mathrm{Sr}$ ratio is very low namely $0.7021 \pm 0.0002$ (Arth et al. 1978).

Hietanen (1943) mentioned that trondhjemitic rocks were produced through magmatic crystallization from a water-rich magma 
Table 5. Analytical results of biotites and hornblendes of the Svecofennian synorogenic granitic rocks, Southwest Finland.

\begin{tabular}{|c|c|c|c|c|c|c|c|c|}
\hline \multirow{2}{*}{\multicolumn{2}{|c|}{ Sample No. }} & \multicolumn{3}{|c|}{ Biotite } & \multicolumn{3}{|c|}{ Hornblende } & \multirow{2}{*}{ Remarks } \\
\hline & & $\mathrm{H}_{2} \mathrm{O}(w \mathrm{t} \%)$ & $\delta D(\% \infty)$ & $x_{\mathrm{Fe}}$ & $\mathrm{H}_{2} \mathrm{O}(\mathrm{wt} \%)$ & $\delta D(\%)$ & $x_{\mathrm{Fe}}$ & \\
\hline 1 & 86081708 & 3.45 & -66.6 & 0.40 & 1.88 & -69.7 & 0.37 & gneissose diorite \\
\hline 2 & 86081701 & 4.21 & -64.3 & 0.49 & 1.90 & -72.0 & 0.56 & $"$ \\
\hline 3 & 86081711 & 3.00 & -70.8 & 0.53 & 1.76 & -68.0 & 0.52 & gneissose granodiorite \\
\hline 4 & 86081715 & 3.56 & -68.2 & 0.40 & 2.07 & -74.1 & 0.34 & gneissose diorite \\
\hline 5 & 86081716 & 3.50 & -74.6 & 0.34 & 2.08 & -64.1 & 0.27 & " \\
\hline 6 & 86081804 & 2.76 & -80.2 & 0.57 & 1.82 & -84.1 & 0.54 & hornblende-bearing trondhjemite \\
\hline 7 & 86081807 & 2.68 & -93.9 & 0.43 & 1.71 & -71.4 & 0.38 & hornblende-biotite tonalite \\
\hline 8 & 86081606 & 2.89 & -87.5 & 0.46 & 1.70 & -72.4 & 0.41 & gneissose gabbroic diorite \\
\hline 9 & 86081608 & 3.48 & -72.5 & 0.43 & 1.92 & -65.5 & 0.38 & gneissose diorite \\
\hline 10 & 86081611 & 3.48 & -76.7 & 0.36 & 2.48 & -64.3 & 0.36 & $"$ \\
\hline
\end{tabular}

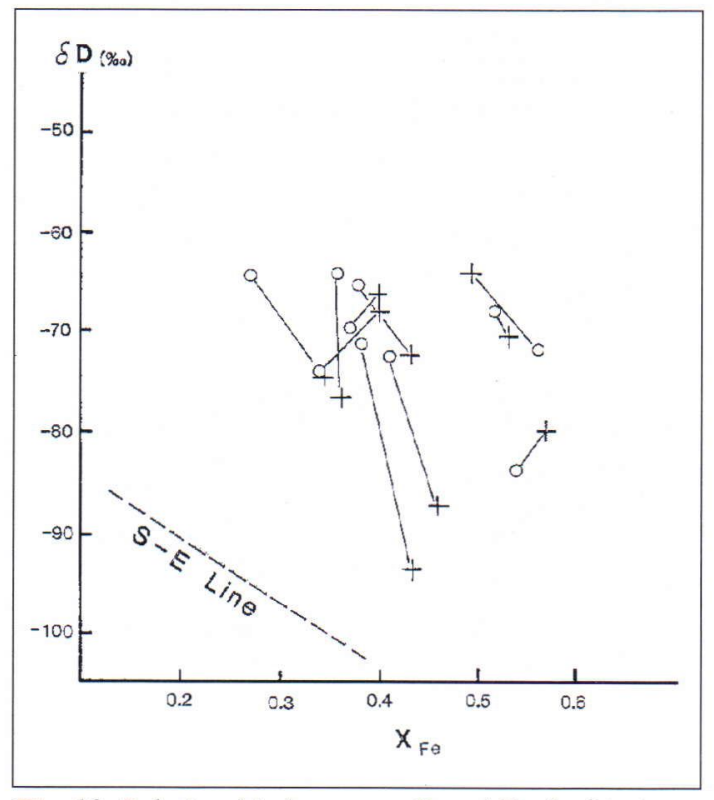

Fig. 10. Relationship between $\sigma D$ and $X_{F e}$ for biotite (cross) and hornblende (circle) from the synorogenic granites around Turku. The $S$-E line Indicates the slope determined by the Suzuoki-Epstein equation.

accompanied by the crystallization of biotite from an early stage of magmatic evolution. He also suggested that some of the water originated in the neighboring pelitic metamorphic rocks. Arth et al.(1978) reported that some of the trondhjemite of the Turku district have high S 180 values (up to $+12.3 \%$, whole rock) due to the exchange of water with their pelitic wall rocks. We collected ten samples, and sample sites are shown in Fig. 9.

The analytical results are presented in Table 5 and Fig. 10. The XFe values of the minerals are scattered, 0.27 to 0.56 for hornblende and 0.3 to 0.57 for biotite. The $\sigma \mathrm{D}$ values of hornblende range from -64 to $-84 \%$, and those of biotite are in the range of -64 to $-94 \%$. The $\sigma \mathrm{D}-\mathrm{XFe}$ relationships of both minerals are rather inconsistent. However, the pattern of some of the tie-lines of coexisting hornblende and biotite is the same as those of island arc granites. Water $(\mathrm{OH})$ contents of both minerals overlap with those of magnetite-series granitic rocks in Japan (Fig. 11).

\section{DISCUSSION}

As mentioned in the previous section, $\sigma \mathrm{D}-\mathrm{XFe}$ relationships of coexisting hornblende and biotite in the Japanese Cretaceous granites are quite different from those of rapakivi granites. Firstly, the relationships of the most Japanese Cretaceous granite are completely concordant with those obtained by the experimental investigation by Suzuoki and Epstein (1976) but those of the rapakivi 


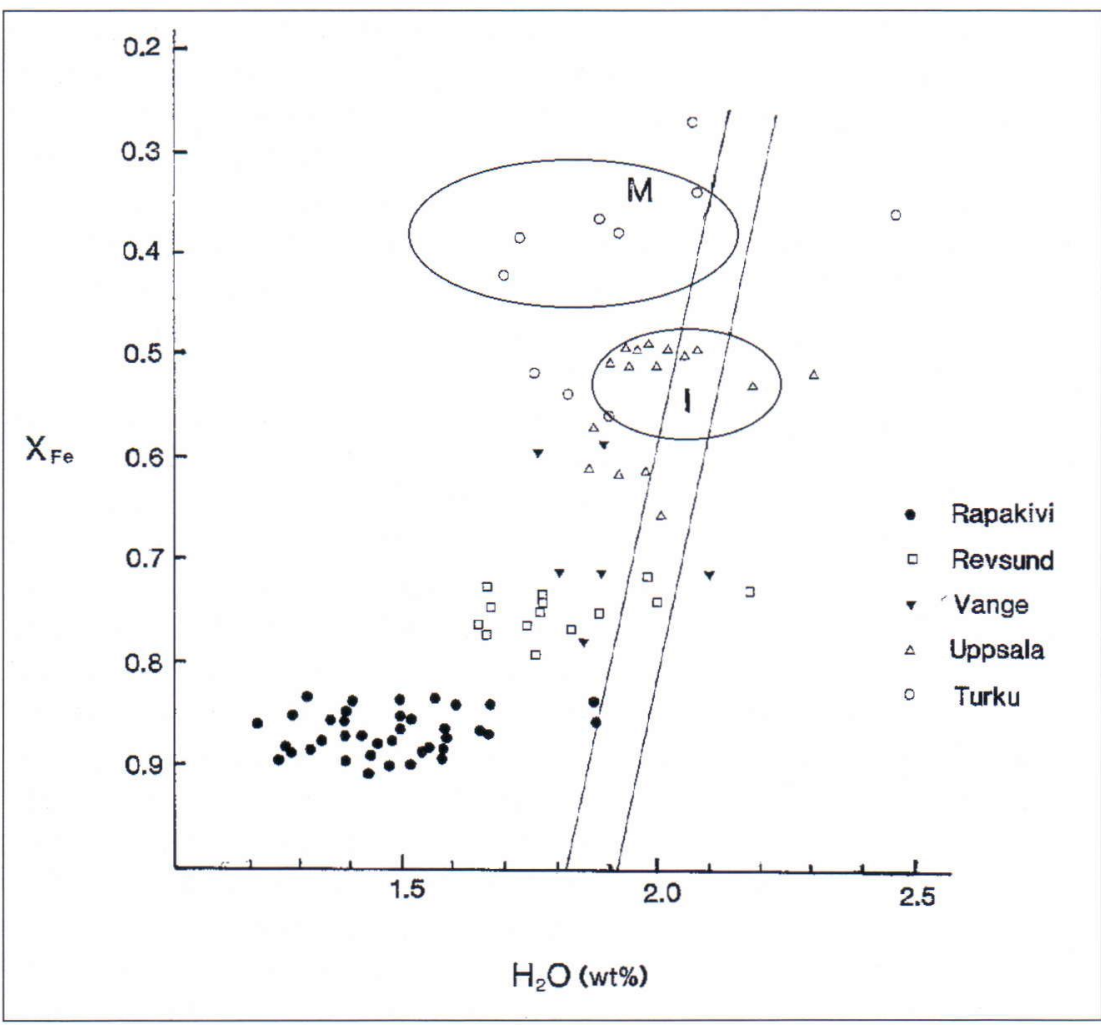

Fig. 11. Relationship

between $X_{F e}$ and water content of hornblende from the Finnish and Swedish granites. The area between two straight lines is for hornblende with stoichiometric water content. $M$ and I are the areas of magnetiteand ilmenite-series granites of the Japanese Islands.

granites are quite different. In other words, the inclinations of the tie-lines of coexisting hornblende and biotite of the former, hornblende being higher in $\sigma \mathrm{D}$ value and lower in XFe than biotite, are almost the same as those

of the experimental results. On the other hand, the tie-lines for the latter are nearly vertical in the $\sigma \mathrm{D}$-XFe diagram with the feature that the $\sigma \mathrm{D}$ value of hornblende is much lower than that of biotite, and high XFe values for both minerals are close to each other. Secondly, XFe values of hornblende and biotite in most of the Japanese granitic rocks are usually lower than 0.6 , but those of rapakivi granites are higher than 0.8 . Furthermore, the $\mathrm{OH}$ content of hornblende is much higher in the Japanese granitic rocks than in the rapakivi granites as seen in Fig. 11. The same trend holds also for biotite.

Since the Suzuoki-Epstein experiment has been conducted under conditions where the amount of molecular water in the crucible is about a hundred times higher than the content of $\mathrm{OH}$ in hydrous silicates, the trend found in the Japanese Cretaceous granitic rocks should be a reflection of the presence of abundant molecular water in the process of crystallization during the magmatic and postmagmatic stage.

The hydrogen isotope exchange experimental study between amphibole and water was performed by Graham et al. (1984), and also the study of the relationship between tremolite or biotite and water was done by Kuroda et al. (1992). However, the results of these experiments were different from the Suzuoki-Epstein result. The difference in the results can be explained by the very small amount of molecular water in the Pt or Au crucibles (only two to three times the molecular water of $\mathrm{OH}$ content of the minerals) compared with the Suzuoki-Epstein experiment. This mechanism would be clarified afterwards.

Anyway, the anorogenic rapakivi granites were intruded into the cratonic crust. The original magma would have been generated in the upper mantle or the lower crust, where the molecular water content must have been quite low. However, such hydrous 
conditions may have been realized by the supply of pore water in non-metamorphic formation through the island arc activities such as subduction, accretion etc.

When the content of the total water $\left(\mathrm{OH}+\mathrm{H}_{2} \mathrm{O}\right)$ in the magma is low, hydroxyl, $\mathrm{OH}$, is the predominant species (Stolper 1982, 1989, Zhang et al., 1991). The direct experimental results for the $\mathrm{D} / \mathrm{H}$ fractionation between $\mathrm{OH}$ in magma and $\mathrm{OH}$ of minerals have not yet been obtained.

According to the analytical results on granites of the Svecofennian belt including unpublished data, $\sigma D$ values of biotite are distributed in a rather narrow range even though $\mathrm{XFe}$ values vary widely. This result indicates that the $\sigma D$ value of biotite does not depend so much on XFe but that of hornblende depends strongly on XFe. In other words, the $\mathrm{D} / \mathrm{H}$ fractionation factors between $\mathrm{OH}$ in magma and $\mathrm{OH}$ of hornblende or biotite are different even though the XFe of both minerals are the same. This assumption contradicts inevitably with the experimental result of fractionation factor between molecular water and biotite, being the same as that between molecular water and hornblende when the $\mathrm{X}_{\mathrm{Fe}}$ value of both minerals is the same. The result of Suzuoki-Epstein's experimental study can only be applicable when molecular water is predominant in a magma-rock system.

We have described the $\sigma \mathrm{D}-\mathrm{XFe}$ relationship between potassic richterite and phlogopite in mica nodules and a peridotite xenolith in South African kimberlite (Kuroda et al. 1975). The patterns are similar to that for the rapakivi granites, i.e. $\sigma D$ values of richterite are much lower than those of phlogopite and XFe values of both minerals are almost the same. As the result, tie-lines are almost vertical in the $\sigma \mathrm{D}-\mathrm{XFe}$ diagram. In this case,

\section{REFERENCES}

Arth, J.G., Barker, F., Peterman, Z. E. \& Friedman, I., 1978. Geochemistry of the gabbro-diorite-tonalitetrondhjemite suite of southwest Finland and its implicatlons for the origin of tonalitic and trondhjemitic magmas. Journal of Petrology 19, 287-316.

Ghose, S., 1965. A scheme of cation distribution in however, the XFe values are very low $(<0.2)$ and the host rocks are ultramafic, so that the conditions of formation are completely different from those of granitic rocks. The only common feature between rapakivi and kimberlite nodules is the deficiency of water in the magma-rock system which is indicated by the higher content of fluorine in hydrous minerals. Also both rocks represent anorogenic cratonic intrusions.

These features are closely related to the geological evolution of the Svecofennian belt. The primary granitic magma formed in the lowest crust or upper mantle is essentially low in total water content. The Turku mass was intruded into the mobile belt where the mass interacted with surrounding material to increase the "total water" content. We may say, that the Uppsala, Vänge and Revsund masses are intermediate in this respect. In the latest stage, the anorogenic granite such as rapakivi intruded into already cratonized crust so that its magma had no chance to suck molecular water, and probably retained the original feature of the partial melting. The high XFe values of hornblende and biotite, as well as the large difference in $\sigma \mathrm{D}$ values of both minerals may represent a part of the features of the original partial melt.

ACKNOWLEDGEMENTS: The authors would like to express their thanks to the Ministry of Education, Science and Culture of Japan for a Grant-in-Aid for Overseas Scientific Survey and a Grant-in-Aid for Scientific Research. The authors' gratitude is extended to Prof.

I. Haapala and Prof. A. Lindh for their cooperation and discussion, and our colleagues Prof. S. Kanisawa, Prof. T. Maruyama and Dr. T. Morikiyo.

IGCP Project 315 (Rapakivi Granites and Related Rocks) Publication Nr 22.

amphibole. Mineralogical Magazine 35, 46-S4.

Graham, C. M., Harmon, R. S. \& Sheppard, S. M. F., 1984. Experimental hydrogen isotope studies: Hydrogen isotope exchange between amphiboles and water. American Mineralogist 69, 128-138.

Haapala, I. \& Rämö, O. T., 1990. Petrogenesis of the Proterozoic rapakivi granites of Finland. Geological Society of America, Special Paper 246, 275-286. Hietanen, A., 1943. Über das Grundgebirge des Ka- 
lantigebietes in südwestlichen Finland. Bulletin de la Commission géologique de Finlande 130, 1-103.

Hietanen, A., 1947. Archean geology of Turku district in south-western Finland. Bulletin of the Geological Society of America 58, 1019-1084.

Härme, M., 1958. General geological map of Finland: Pre-Quaternary rocks (1:400,000). Sheet B-1. Turku. Geological Survey of Finland.

Härme, M., 1980. General geological map of Finland Pre-Quarternary rocks (1:400,000). Sheet C-1, D-1. Helsinki. Geological Survey of Finland.

Ishihara, S., 1977. The magnetite-series and ilmeniteseries granitic rocks. Mining Geology 27, 293-305. Kuroda, Y., 1990. Role of water in the evolution of granitic magma. Journal Geological Society of Japan 96, 775-786.

Kuroda, Y., Suzuoki, T., Matsuo, S. \& Aoki, K., 1975. $\mathrm{D} / \mathrm{H}$ ratios of the coexisting phlogopite and richterite from mica nodules and peridotite in South African kimberlite. Contributions to Mineralogy and Petrology 52, 315-318.

Kuroda, Y., Yamada, T., Fujimoto, K., Suzuoki, T. \& Matsuo, S., 1978. Hydrogen isotope study on biotite and hornblende from Finnish granitic rocks. Geochemical Journal 12, 259-263.

Kuroda, Y., Yamada, T. \& Morikiyo, T., 1985. Some considerations on behavior of fluids during the formation of granite and metamorphic rocks (Abstract). Report of Dynamic Processes of Transformation in the Earth Interior, 16-19.

Kuroda, Y., Yamada, T., Kobayashi, H., Ohtomo, Y., Yagi, M. \& Matsuo, S., 1986. Hydrogen isotope study of the granitic rocks of the Ryoke belt, central Japan. Chemical Geology (Isotope Geoscience Section) 58, 283-302.

Kuroda, Y., Yamada. T., Takano, O. \& Matsuo, S., 1989. D/H study of the magnetite-series granitic plutons from the Kitakami district, Northeast Japan. Chemical Geology (Isotope Geoscience Section) 73, 343-352.

Kuroda, Y., Yamada, T., Hariya, Y. \& Matsuo, S., 1992. Hydrogen partition experimental work between magma and hydrous silicates. Report of Grant-in-Aid for Scientific Resear-ch, No. 01S40655, 1-15.

Lundqvist, T., 1979. The Precambrian of Sweden. Sveriges Geologiska Undersökning, Series C 768, 187.

Lundqvist, T., 1987. Bedrock geology of Västernorrland County $(1: 200,000)$. Sveriges GeologiskaUndersökning, Series Ba 31.

Müllern, C-F., Thunholm, B., Lundegårdh, P. H. \& Stålhös, G., 1983. Bedrock map of Uppsala County (1:250,000). Sveriges Geologiska Undersökning, Series Ah 5.
Petchett, J. \& Kouvo, O., 1986. Origin of continental crust of 1.9-1.7 Ga age: $\mathrm{Nd}$ isotope and $\mathrm{U}-\mathrm{Pb}$ zircon ages in the Sveco- Karelian terrain of South Finland. Contribution to Mineralogy and Petrology 92, 1-12. Persson, L., 1978. The Revsund-Sörvik granites in the western part of the province of Angermanland, central Sweden. Sveriges Geologiska Undersökning, Series C 741, 1-59.

Simonen, A., 1960. Plutonic rocks of the Svecofennides in Finland. Bulletin de la Commission géologique de Finlande 189, 1-101.

Simonen, A. \& Vorma, A., 1969. Amphibole and biotite from rapakivi. Bulletin de la Commission géologique de Finlande 238, 1-28.

Stolper, E., 1982. Speciation of water in silicate melts. Geochimica Cosmochimica Acta 96, 2609-2620.

Stolper, E., 1989. Temperature dependence of the speciation of water in rhyolite melts and glasses. American Mineralogist 74, 1247- 1257.

Suzuoki, T. \& Epstein S., 1976. Hydrogen fractionation between $\mathrm{OH}$-bearing silicate minerals and water. Geochimica Cosmochimica Acta 40, 1229-1240.

Vaasjoki, M., 1977. Rapakivi granite and other postorogenic rocks in Finland: Their age and the lead isotopic composition of certain associated galena mineralization. Geological Survey of Finland, Bulletin 294, 1-64.

Vaasjoki, M., Rämö, O.T. \& Sakko, M., 1991. New U-Pb ages from the Wiborg rapakivi area: Constraints on the temporal evolution of the rapakivi graniteanorthosite-diabase dyke association of southeastern Finland. In: Haapala, I. \& Condie, K. D. (Eds) Precambrian granitoids-petrogenesis, geochemistry and metallogeny. Precambrian Research 51, 227-243.

Vorma, A., 1976. On the petrochemistry of rapakivi granite with special reference to the Laitila massif, southwestern Finland. Geological Survey of Finland, Bulletin 285, 1-98.

Welin, E., Christiansson, K.\& Nilsson, Ö., 1971. Rb-Sr radiometric ages of extrusive and intrusive rocks in northern Sweden I. Sveriges Geologiska Undersökning, Series C 666, 1-38.

Welin, E., Einarsson, Ö, Gustafsson, B., Lindberg. R., Christiansson, K., Johansson, G. \& Nllsson, Ö. 1977. Radiometric ages of intrusive rocks in northern Sweden II. Sveriges Geologiska Undersökning, Series C 731, 1-21.

Welin, E., Kähr, A.M. \& Lundergårdh, P.H., 1980. $\mathrm{Rb}-\mathrm{Sr}$ isotope systematics at amphibolite facies conditions, Uppsala region, eastern Sweden. Precambrian Research 13, 87-101.

Zhang, Y., Stolper, E.M. \& Wasserburg, G. J., 1991. Diffusion of water in rhyolitic glasses. Geochimica Cosmochimica Acta 55, 441-456. 